\title{
Nota
}

\section{INFLUENCE OF LIMING ON RESIDUAL SOIL RESPIRATION AND CHEMICAL PROPERTIES IN A TROPICAL NO-TILLAGE SYSTEM(1) $^{(1)}$}

\author{
Adolfo Valente Marcelo( ${ }^{(2)}$, José Eduardo Corá(3) \& Newton La Scala Junior(4)
}

\begin{abstract}
SUMMARY
Because of the climate changes occurring across the planet, especially global warming, the different forms of agricultural soil use have attracted researchers' attention. Changes in soil management may influence soil respiration and, consequently, $C$ sequestration. The objectives of this study were to evaluate the long-term influence of liming on soil respiration and correlate it with soil chemical properties after two years of liming in a no-tillage system. A randomized complete block design was used with six replications. The experimental treatments consisted of four lime rates and a control treatment without lime. Two years after liming, soil $\mathrm{CO}_{2}$ emission was measured and the soil sampled

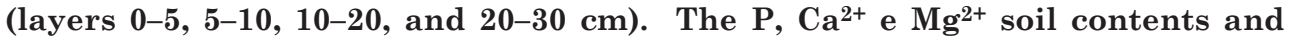
pH and base saturation were determined. $\mathrm{CO}_{2}$ emission from soil limed at the recommended rate was $24.1 \%$ higher, and at twice the recommended rate, $47.4 \%$ higher than from unlimed soil. Liming improved the chemical properties, and the linear increase in soil respiration rate correlated positively with the $\mathrm{P}, \mathrm{Ca}^{2+}$ and $\mathrm{Mg}^{2+}$ soil contents, $\mathrm{pH}$ and base saturation, and negatively with $\mathrm{H}+\mathrm{Al}$ and $\mathrm{Al}^{3+}$ contents. The correlation coefficient between soil respiration rate and chemical properties was highest in the 10-20 cm layer.
\end{abstract}

Index terms: Soil $\mathrm{CO}_{2}$ emission, limestone, soil fertility.

(1) Received for publication in March 3, 2011 and approved in October 8, 2011.

(2) Ph.D. student from Agronomy Graduate School (Crop Production) - UNESP, Campus of Jaboticabal. Via de Acesso Prof. Paulo Donato Castellane, 14884-900, Jaboticabal, São Paulo, Brazil. E-mail: adolfovalente@yahoo.com.br

(3) Associate Professor of Soil Science Department, São Paulo State University - UNESP, Campus of Jaboticabal. CNPq Researcher. E-mail: cora@fcav.unesp.br

(4) Associate Professor of Exact Sciences Department, São Paulo State University - UNESP, Campus of Jaboticabal. E-mail: lascala@ fcav.unesp.br 


\title{
RESUMO: EFEITO RESIDUAL DA CALAGEM NA RESPIRAÇÃO DO SOLO E NOS SEUS ATRIBUTOS QUÍMICOS EM SEMEADURA DIRETA NOS TRÓPICOS
}

\begin{abstract}
Devido às mudanças climáticas do planeta, principalmente ao aquecimento global, as formas de utilização dos solos na agricultura têm atraído grande atenção de pesquisadores. Mudanças de manejo podem influenciar a respiração do solo e, por conseguinte, alterar drasticamente o sequestro de C. Os objetivos deste trabalho foram avaliar, em semeadura direta, a influência da calagem nas emissões de $\mathrm{CO}_{2}$ do solo e correlacioná-las aos atributos químicos deste após dois anos da calagem. Utilizou-se o delineamento em blocos casualizados, com seis repetições. Os tratamentos constituíram de quatro doses de calcário e uma testemunha. Decorridos dois anos da calagem, avaliou-se a emissão residual de $\mathrm{CO}_{2}$ do solo, coletaram-se amostras nas camadas de 0-5, 5-10, 10-20 e 20-30 cm de profundidade e determinaram-se os teores de $\mathrm{P}, \mathrm{Ca}^{2+}$ e $\mathrm{Mg}^{2+}$ e valores de $\mathrm{pH}$ e de saturação por bases. A emissão residual de $\mathrm{CO}_{2}$ do solo, quando a dose recomendada foi aplicada, foi $24,1 \%$ superior, quando comparada à do solo sem aplicação de calcário, e 47,4\% maior, quando se aplicou o dobro da dose recomendada. A calagem melhorou as condições químicas do solo, e a emissão de $\mathrm{CO}_{2}$ aumentou linearmente com o aumento das doses. A emissão de $\mathrm{CO}_{2}$ do solo apresentou correlações positivas com os teores de $\mathrm{P}, \mathrm{Ca}^{2+}$ e $\mathrm{Mg}^{2+}$ e com os valores de $\mathrm{pH}$ e de saturação por bases e negativas com os teores de $\mathrm{H}+\mathrm{Al}$ e $\mathrm{Al}^{3+}$. Maiores coeficientes de correlação entre as taxas de emissão de $\mathrm{CO}_{2}$ do solo e os atributos químicos deste ocorreram na camada de 10-20 cm.
\end{abstract}

Termos de indexação: respiração do solo, calcário, fertilidade do solo.

\section{INTRODUCTION}

The expected population increase in the coming decades indicates directions that seem paradoxical: more food and energy production are needed together with environmental protection. Reports of the Intergovernmental Panel on Climate Change (IPCC) emphasized the need for adaptation in several production areas, including Latin America, as higher temperatures and drier periods are expected (IPCC, 2007). Therefore, in the near future, agricultural production should be adapted to the changing climate and, if possible, help mitigate atmospheric greenhouse gases, above all $\mathrm{CO}_{2}$ (Bernoux et al., 2005; Cerri et al., 2007).

Because of the climate changes across the planet, particularly global warming, the different forms of agricultural soil use have attracted researchers' attention (Batjes, 1998; Adachi et al., 2006; Costa et al., 2008; McLain \& Ahmann, 2008; Li et al., 2009). According to Li et al. (2009), changes in soil management may influence soil respiration and, as a consequence, drastically affect $\mathrm{C}$ sequestration. The increase of $\mathrm{CO}_{2}$ concentration in the atmosphere is partially due to respiration from the microbial activity in the soil (IPCC, 2007).

In the huge regions with acidic soils in Brazil, liming is commonly used to correct soil acidity, which can represent an important source of $\mathrm{CO}_{2}$ efflux (Bernoux et al., 2003; Amaral et al., 2004). Some studies have shown that liming is one of the greatest factors of gas emissions that are responsible for global warming (Bernoux et al., 2003; Cerri et al., 2006). This is caused by the increased $\mathrm{CO}_{2}$ flow to the atmosphere, as a result of $\mathrm{CaCO}_{3}$ hydrolysis reactions in the soil. Additionally, microbial activity, intensified by the improved soil chemical conditions after liming, has to be considered (Chan \& Heenan, 1998; Adachi et al., 2009). According to the IPCC (2007), soil respiration associated with liming practices is estimated based on the limestone composition and the annually applied lime rate. For this estimation, the amount applied is multiplied by the emissions factors, which results in the $\mathrm{CO}_{2}$ amount released from the soil to the atmosphere. Based on the amount of limestone used in Brazilian agriculture from 1990 to 2000, the average annual liming-related soil respiration was estimated at 7.2 $\mathrm{Tg} \mathrm{CO}$ (Bernoux et al., 2003, 2005). However, this value would be underestimated, if the chemical reactions and the residual effects of liming lasted longer than a year.

The objectives of this study were to evaluate the long-term influence of liming on soil respiration and correlate it with soil chemical properties two years after liming in a no-tillage system.

\section{MATERIAL AND METHODS}

The experiment was conducted in Jaboticabal, SP, Brazil $\left(21^{\circ} 15^{\prime} 22^{\prime}\right.$ S, $48^{\circ} 18^{\prime} 58^{\prime \prime} \mathrm{W} ; 595 \mathrm{~m}$ 
asl). The climate, according to Köppen, is Aw (Tropical climate with a dry season), with a mean annual rainfall of $1,425 \mathrm{~mm}$, mostly concentrated between October and March. The average annual temperature is $22{ }^{\circ} \mathrm{C}$ and average relative air humidity $70 \%$.

The soil in the experimental area is Red Oxisol, based on the American Soil Taxonomy (Soil Survey Staff, 2003). Texture analysis showed soil contents of: $642 \mathrm{~g} \mathrm{~kg}^{-1}$ sand, $315 \mathrm{~g} \mathrm{~kg}^{-1}$ clay, and $43 \mathrm{~g} \mathrm{~kg}^{-1}$ silt in the $0-20 \mathrm{~cm}$ layer. Chemical analysis of the topsoil $(0-20 \mathrm{~cm})$ prior to the experiment showed values of: $\mathrm{pH}\left(\mathrm{CaCl}_{2}\right)=4.5$; organic matter $=17 \mathrm{~g} \mathrm{~kg}^{-1} ; \mathrm{P}$ (resin) $=12 \mathrm{mg} \mathrm{dm}^{-3}$; in $\mathrm{mmol}_{\mathrm{c}} \mathrm{dm}^{-3}: \mathrm{K}=1.1, \mathrm{Ca}=11, \mathrm{Mg}$ $=5, \mathrm{H}+\mathrm{Al}=40$; cation exchange capacity $(\mathrm{CEC})=$ 56.6 ; and base saturation $=29 \%$.

Until 1995, the field had been used for corn (Zea mays L.) and soybean (Glycine max L. Merrill) rotation under conventional tillage for more than 10 years. From 1995 to August 2000, the field was left fallow. In September 2000, the management was changed to no-tillage corn-soybean rotation, left fallow in the fall/winter.

A randomized complete block design was used with six replications. The experimental treatments consisted of four lime rates and a control without lime, on $20 \mathrm{~m}^{2}$ plots. Lime was applied at 0.9 , 1.8, 2.7 and $3.6 \mathrm{Mg} \mathrm{ha}^{-1}$ (i.e., 0.5, 1.0, 1.5 and 2.0 times the limestone requirement to raise the soil base saturation to $60 \%$ ), determined based on the soil chemical analysis and the calcium carbonate equivalent $(\mathrm{CCE})=100 \%$. The soil surface was limed by hand, without moldboard plowing on 1 Sept, 2000.

Two years after liming (September 2002), soil respiration emission was measured in the previous crop inter-rows. Emissions were recorded using a soil chamber (internal volume $991 \mathrm{~cm}^{3}$, exposed area of $\left.71.6 \mathrm{~cm}^{2}\right)$ manufactured by the LI-COR company (LI-6400-09, LI-COR, NE, EUA) coupled to a photosynthesis analysis system. The chamber was placed on the top of PVC plastic rings (diameter $10 \mathrm{~cm}$ ) and installed on the soil one day before the readings. The chamber was coupled to the portable photosynthesis analysis system (LI-6400), which analyzes the internal $\mathrm{CO}_{2}$ concentration by optical absorption spectroscopy. Before each reading, the $\mathrm{CO}_{2}$ concentration within the chamber was reduced to $370 \mu \mathrm{mol} \mathrm{mol}-1$ (370 ppmv) by passing the air through soda lime for a few seconds.

After the chamber was installed over the plastic rings, the soil $\mathrm{CO}_{2}$ emission was measured every $2.5 \mathrm{~s}$, and the total $\mathrm{CO}_{2}$ emission was calculated after $90 \mathrm{~s}$, which is when the concentration of $\mathrm{CO}_{2}$ in the interior of the chamber reached $390 \mu \mathrm{mol} \mathrm{mol}^{-1}$. At the end of the measurement phase, a linear regression between $\mathrm{CO}_{2}$ emissions and $\mathrm{CO}_{2}$ concentration in the inner chamber was determined. This regression equation was then used to calculate $\mathrm{CO}_{2}$ emissions from the soil for a concentration of $380 \mu \mathrm{mol} \mathrm{mol}{ }^{-1}$ in the chamber, which was the $\mathrm{CO}_{2}$ concentration in the air near the soil measured at the beginning of each set of measurements. The measurements were carried out in triplicate on each experimental plot.

After the respiration measurements, soil samples were obtained from each plot (layers $0-5,5-10,10$ 20 and $20-30 \mathrm{~cm}$ ). Six samples per plot were mixed to a composite sample for each soil layer. After sampling, the air-dried soil was sieved $(2 \mathrm{~mm})$. The total $\mathrm{C}, \mathrm{pH}\left(\mathrm{CaCl}_{2}\right)$, resin- $\mathrm{P}$, exchangeable $\mathrm{K}^{+}, \mathrm{Ca}^{2+}$, $\mathrm{Mg}^{2+}$ and $\mathrm{Al}^{3+}, \mathrm{H}+\mathrm{Al}$, CEC, and base saturation were determined for each sample, according to standard procedures described by Page et al. (1982).

Soil respiration data were statistically analyzed (ANOVA). Due to the significance of results $(p<0.10)$, the effects of lime rates were subjected to polynomial regression analysis $(\mathrm{p}<0.10)$. Correlation analyses $(p<0.10)$ were carried out to detect significant functional relationships between soil respiration and chemical properties.

\section{RESULTS AND DISCUSSION}

The results showed significant effect $(p<0.10)$ of lime rates on soil respiration, even two years after liming. Soil respiration increased linearly with increasing lime rates (Figure 1). It is worth noting that each soil respiration value was obtained in 18 measurements, ensuring a high degree of representativeness. The angular coefficient of

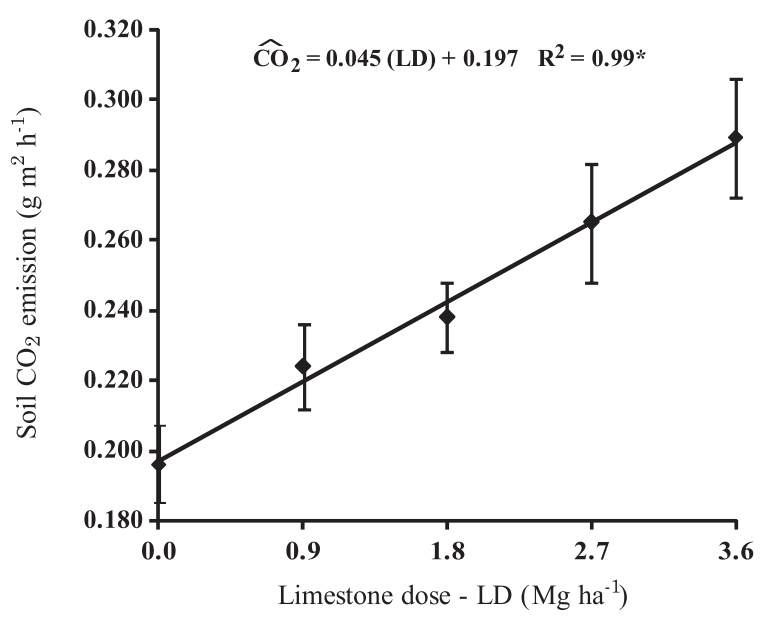

Figure 1. Linear regression model for lime rates and soil $\mathrm{CO}_{2}$ emission, two years after liming without moldboard plowing. * Significantly different $(p<0.10)$. Error bars represent one standard error of the mean. 
the adjusted model (0.045), which represents the sensitivity of soil $\mathrm{CO}_{2}$ emission, demonstrated clear differences among the treatments: zero lime, recommended rate $\left(1.8 \mathrm{Mg} \mathrm{ha}^{-1}\right)$ and twice the recommended rate $\left(3.6 \mathrm{Mg} \mathrm{ha}^{-1}\right)$. The highest lime rate increased soil respiration by $47.4 \%$ compared to the unlimed treatment and by $24.1 \%$ compared with the recommended rate, as adequate for plants (lime requirement to raise base saturation to $60 \%$ ). Results show that the liming rates applied to the soil directly affected soil respiration, even two years after liming.

The IPCC method to calculate the liming-related soil respiration is based on the lime amount used in one year multiplied by emission factors, which depend on the chemical composition of the limestone. Then, the soil $\mathrm{CO}_{2}$ effluxes are represented in released $\mathrm{CO}_{2}$ mass units related to the lime amount applied per year (IPCC, 2007). Consequently, the soil respiration due to the residual effect of liming (after more than a year) is not taken into consideration by the IPCC method. Therefore, the results obtained in this study indicate that the IPCC method may underestimate soil respiration because the limestone, after two years, kept on reacting in the soil, and its effects lasted longer than considered by the IPCC.

According to Fuentes et al. (2006), the fast $\mathrm{CO}_{2}$ release from the soil after liming is a result of two parallel processes: a chemical process, as consequence of the $\mathrm{CaCO}_{3}$ hydrolysis reaction in the soil; and a biological process caused by the increased microbial activity in the soil, due to the improvement of soil chemical conditions. In the
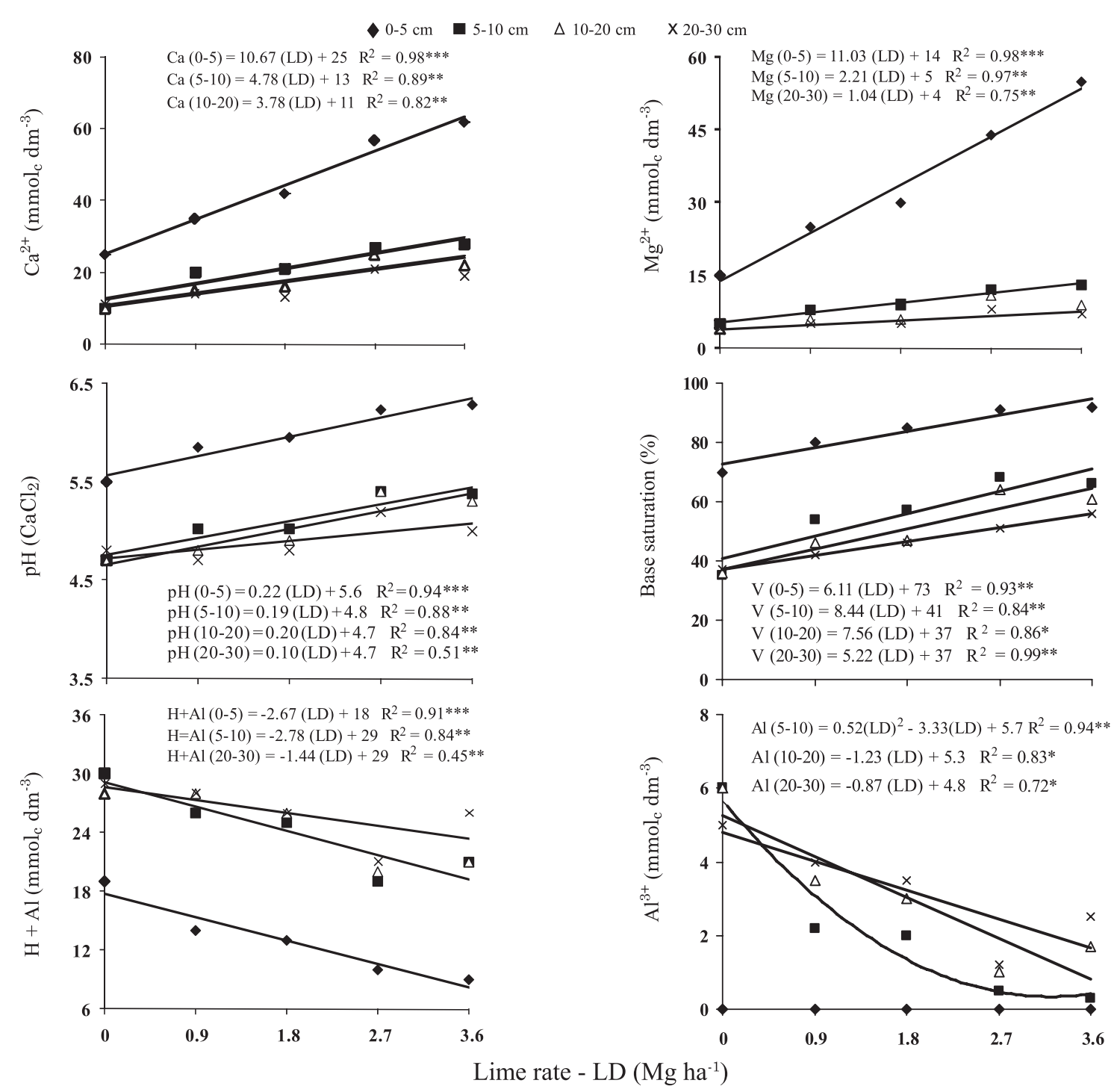

Figure 2. Exchangeable $\mathrm{Ca}^{2+}, \mathrm{Mg}^{2+}, \mathrm{Al}^{3+}$ and potential acidity $(\mathrm{H}+\mathrm{Al})$ contents and $\mathrm{pH}$ and base saturation values with lime rates, two years after liming. *: (significantly $p<0.10)$; ** (significantly $p<0.05)$; ***: (significantly $\mathrm{p}<0.01)$. 
present study, probably, the major contribution to soil respiration increase was the result of biological processes, because liming was carried out two years before the soil respiration measurements. Liming improved the chemical conditions in the soil profile (Figure 2), favoring microbial biomass activity and growth (Haynes \& Swift, 1988; La Scala Junior et al., 2000), which increased the microbial respiration rate and soil $\mathrm{CO}_{2}$ emission with increasing lime rates (Figure 1).

Similar results were reported by Fuentes et al. (2006), who stated that the increase of soil $\mathrm{pH}$ provided by liming affects the activity and microbial population in the soil. However, the authors pointed out that these effects depend on soil type and soil management. In acidic soils, Neale et al. (1997) observed that liming improved chemical and environmental conditions in the soil, promoting the development of acid-intolerant microorganisms, which leads an increase in soil microbial biomass and respiration. In an evaluation of the population of bacteria after liming $\left(7.5 \mathrm{Mg} \mathrm{ha}^{-1}\right)$ in acidic soil, Shah et al. (1990) noticed a 20 fold increase in the amount of bacteria.

However, the $\mathrm{CO}_{2}$-releasing $\mathrm{CaCO}_{3}$ hydrolysis reaction must be taken into account because correlations between soil chemical properties and respiration have been verified, even in the deepest soil layer. In the $0-5 \mathrm{~cm}$ layer, soil respiration correlated $(\mathrm{p}<0.10)$ with P-resin $(\mathrm{r}=0.42), \mathrm{Ca}^{2+}$ $(\mathrm{r}=0.40), \mathrm{H}+\mathrm{Al}(\mathrm{r}=-0.45)$ and base saturation $(\mathrm{r}=0.38)$; in the $5-10 \mathrm{~cm}$ layer, it correlated with $\mathrm{Ca}^{2+}(\mathrm{r}=0.35)$ and $\mathrm{Al}^{3+}(\mathrm{r}=-0.38)$; in the $10-20 \mathrm{~cm}$ layer, with $\mathrm{pH}(\mathrm{r}=0.43), \mathrm{Ca}^{2+}(\mathrm{r}=0.41), \mathrm{H}+\mathrm{Al}(\mathrm{r}=$ -0.36), $\mathrm{Al}^{3+}(\mathrm{r}=-0.35)$ and base saturation $(\mathrm{r}=0.40)$; and in the 20-30 cm layer, with $\mathrm{Ca}^{2+}(\mathrm{r}=0.42)$, $\mathrm{Mg}^{2+}(\mathrm{r}=0.39)$ and $\mathrm{Al}^{3+}(\mathrm{r}=-0.39)$.

These values could be related to the downward movement of limestone, which occurred in the two years after application on the soil surface, while it kept reacting with soil at greater depths (Figure 2), releasing $\mathrm{CO}_{2}$ from $\mathrm{CaCO}_{3}$ hydrolysis. Still, there is no doubt that at these depths, liming also improves the soil chemical conditions, favoring increased microbial activity (Shah et al., 1990; Nealy et al., 1997; Fuentes et al., 2006). However, it is known that at lower depths the microbial population is much smaller and contributes less to soil respiration than in the topsoil.

Changes in the soil chemical conditions of subsurface layers, such as potential acidity reduction and increase of $\mathrm{pH}$ and $\mathrm{Ca}^{2+}$ and $\mathrm{Mg}^{2+}$ content, have already been shown in no-tillage systems (Oliveira \& Pavan, 1996; Mello et al., 2003; Caires et al., 2006). These changes occur for the following reasons: 1) the physical downward movement of limestone particles, transported through bio-pores formed after the decomposition of dead roots (Oliveira \& Pavan, 1996) or by soil organisms (Mello et al., 2003), which remain intact due to the no-tillage farming system; 2) the downward movement of $\mathrm{Ca}^{2+}$ and $\mathrm{Mg}^{2+}$ ions bonded to $\mathrm{NO}_{3}{ }^{-}$or $\mathrm{SO}_{4}{ }^{2-}\left(\mathrm{NO}_{3}{ }^{-}\right.$or $\mathrm{SO}_{4}{ }^{2-}$ originated from fertilizer or were released by the mineralization of organic matter) (Mello et al., 2003); 3) or even by the formation of water-soluble organic complexes present in plant residues left on the soil surface in no-tillage systems (Franchini et al., 2001). These organic compounds, bonded with $\mathrm{Ca}^{2+}$ or $\mathrm{Mg}^{2+}$, form $\mathrm{CaL}^{0}$ or $\mathrm{CaL}$ type complexes, making them more mobile in the soil.

Nevertheless, it is believed that a combination of these mechanisms is most likely to have occurred in the system studied here. This combination of mechanisms explains the movement of limestone and of its reaction products to the deeper layers, where it improves the soil chemical conditions or even undergoes hydrolysis, resulting in increased soil respiration in both cases.

The correlation between soil $\mathrm{P}$ content and respiration from the $0-5 \mathrm{~cm}$ layer can be attributed to the increase in $\mathrm{P}$ availability at higher soil $\mathrm{pH}$, as a result of liming (Haynes \& Swift, 1988).

The absence of $\mathrm{Al}^{3+}$ observed in the $0-5 \mathrm{~cm}$ layer (Figure 2) is a result of the precipitation of $\mathrm{Al}^{3+}$ in the soil solution when the $\mathrm{pH}$ of the medium reaches values $\geq 5.5$, eliminating aluminum in the chemical form $\mathrm{Al}^{3+}$ from the soil solution (McBride, 1994).

There was no significant correlation between soil respiration and $\mathrm{K}^{+}$, organic matter content or CEC. These results may be due to the fact that liming does not affect these soil chemical properties straightforwardly. Liming does directly influence the soil $\mathrm{pH}$ and $\mathrm{Ca}^{2+}, \mathrm{Mg}^{2+}$, and $\mathrm{H}+\mathrm{Al}$ soil contents, which in turn affect microbial activity and, consequently, soil respiration. Changes in the organic matter content occur slowly, and could not be detected in the present study because of the short period after liming. The same explanation applies to soil CEC, which is directly linked to the soil organic matter content in tropical systems.

\section{CONCLUSIONS}

1. The soil $\mathrm{CO}_{2}$ emission rate increased linearly with increasing liming rates in a no-tillage system even two years after liming.

2 . When the recommended lime rate to raise soil base saturation to $60 \%$ was applied, soil respiration was $24.1 \%$ higher than from unlimed soil two years later, and $47.4 \%$ higher when twice the recommended rate had been applied. 


\section{LITERATURE CITED}

ADACHI, M.; BEKKU, Y.S.; RASHIDAH, W.; OKUDA, T. \& KOIZUMI, H. Differences in soil respiration between different tropical ecosystems. Appl. Soil Ecol., 34:258-265, 2006.

ADACHI, M.; ISHIDA, A.; BUNYAVEJCHEWIN, S.; OKUDA, T. \& KOIZUM, H. Spatial and temporal variation in soil respiration in a seasonally dry tropical forest, Thailand. J. Trop. Ecol., 25:531-539, 2009.

AMARAL, A.S.; ANGHINONI, I.; HINRICHS, R. \& BERTOL, I. Movimentação de partículas de calcário no perfil de um Cambissolo em Plantio Direto. R. Bras. Ci. Solo, 28:359367, 2004.

BATJES, N.H. Mitigation of atmospheric $\mathrm{CO}_{2}$ concentrations by increased carbon sequestration in the soil. Biol. Fert. Soils, 27:230-235, 1998 .

BERNOUX, M.; VOLKOFF, B.; CARVALHO, M.C.S. \& CERRI, C.C. $\mathrm{CO}_{2}$ emissions from liming of agricultural soils in Brazil. Global Biogeochem. Cycles, 17:1049-1052, 2003.

BERNOUX, M.; CERRI, C.C.; VOLKOFF, B.; CARVALHO, M.C.S.; FELLER, C.; CERRI, C.E.P.; ESCHENBRENNER, V.; PICCOLO, M.C. \& FEIGL, B. Gases do efeito estufa e estoques de carbono nos solos: inventário do Brasil. Caderno Ci. Tecnol, 22:235-246, 2005.

CAIRES, E.F.; GARBUIO, F.J.; ALLEONI, L.R.F. \& CAMBRI, M.A. Surface lime application and black oat cover preceding corn and soybean crops under a no-till system. J. Braz. Soil Sci., 30:87-98, 2006.

CERRI, C.C.; BERNOUX, M.; CARVALHO, M.C.S. \& VOLKOFF, B. Primeiro inventário brasileiro de emissões antrópicas de gases de efeito estufa: Emissões e remoções de dióxido de carbono pelos solos por mudanças de uso da terra e calagem. Brasília, Ministério da Agricultura, 2006. 47p.

CERRI, C.E.P.; SPAROVEK, G.; BERNOUX, M.; EASTERLING, W.E.; MELILLO, J.M. \& CERRI, C.C. Tropical agriculture and global warming: Impacts and mitigation options. Sci. Agric., 64:83-99, 2007.

CHAN, K.Y. \& HEENAN, D.P. Effect of lime $\left(\mathrm{CaCO}_{3}\right)$ application on soil structural stability of a red earth. Aust. J. Soil Res, 36:73-86, 1998

COSTA, F.S.; BAYER, C.; ZANATTA, J.A. \& MIELNICZUK, J. Estoque de carbono orgânico no solo e emissões de dióxido de carbono influenciadas por sistemas de manejo no Sul do Brasil. R. Bras. Ci. Solo, 32:323-332, 2008.

FRANCHINI, J.C.; GONZALEZ-VILA, F.J.; CABRERA, F.; MIYAZAWA, M. \& PAVAN, M.A. Rapid transformations of plant water-soluble organic compounds in relation to cation mobilization in an acid Oxisol. Plant Soil, 231:55-63, 2001.
FUENTES, J.P.; BEZDICEK, D.F.; FLURY, M.; ALBRECHT, S. \& SMITH, J.L. Microbial activity affected by lime in a long-term no-till soil. Soil Tillage Res., 88:123-131, 2006.

HAYNES, R.J. \& SWIFT, R.S. Effects of lime and phosphate additions on changes in enzyme activities, microbial biomass and levels of extractable nitrogen, sulphur and phosphorus in an acid soil. Biol. Fert. Soils, 6:153-158, 1988.

INTERGOVERNMENTAL PANEL ON CLIMATE CHANGE - IPCC. Climate change. The physical science basis. Contribution of Working Group I to the fourth Assessment Report of the Intergovernmental Panel on Climate Change Cambridge, Cambridge University Press, 2007. 996p.

La SCALA JUNIOR, N.; MARQUES JUNIOR, J.; PEREIRA, G.T. \& CORÁ, J.E. Carbon dioxide emission related to chemical properties of a tropical bare soil. Soil Biol. Biochem., $32: 1469-1473,2000$

LI, H.; HAN, X.; QIAO, Y.; HOU, X. \& XING, B. Carbon dioxide emission from black soil as influenced by land-use change and long-term fertilization. Comm. Soil Sci. Plant Anal., 40:1350-1368, 2009.

McBRIDE, M.B. Environmental chemistry of soils. Oxford, Press University, 1994. 406p.

McLAIN, J.E.T. \& AHMANN, D.M. Increased moisture and methanogenesis contribute to reduced methane oxidation in elevated $\mathrm{CO}_{2}$. Biol. Fert. Soils, 44:623-631, 2008.

MELLO, J.C.A.; VILLAS BÔAS, R.L.; LIMA, E.V.; CRUSCIOL, C.A.C. \& BÜLL, L.T. Alterações nos atributos químicos de um Latossolo distroférrico decorrentes da granulometria e doses de calcário em sistemas de plantio direto e convencional. R. Bras. Ci. Solo, 27:553-561, 2003.

NEALE, S.P.; SHAH, Z. \& ADAMS, W.A. Changes in microbial biomass and nitrogen turnover in acidic organic soils following liming. Soil Biol. Biochem., 29:1463-1474, 1997.

OLIVEIRA, E.L. \& PAVAN, M.A. Control of soil acidity in notillage system for soybean production. Soil Tillage Res., 38:47-57, 1996.

PAGE, A.L.; MILLER, R.M. \& KEENEY, D.R., eds. Methods of soil analysis: Chemical and microbiological properties. Madison, American Society Agronomy, 1982. Part 2. 1159p.

SOIL SURVEY STAFF. Keys to soil taxonomy. 9.ed. Washington, USDA-NRCS, 2003. (Handbook, 436)

SHAH, Z.; ADAMS, W.A. \& HAVEN, C.D.V. Composition and activity of the microbial population in an acidic upland soil and effects of liming. Soil Biol. Biochem., 22:257-263, 1990. 